\title{
VAKSINASI LANSIA UPAYA PREVENTIF MENINGKATKAN IMUNITAS AKIBAT PROSES PENUAAN
}

\author{
Nurlaili Susanti \\ Jurusan Biologi, Fakultas Sains dan Teknologi UIN Maliki Malang
}

\begin{abstract}
Advancement in health sciences and technologies gives positive impact to improve life expectancy, but the other hand it can increases elderly population with all consequences. Old age is associated with high morbidity and mortality due to their susceptibility to suffer several diseases caused by lacking immunity, especially infectious diseases. Moreover, the occurrence of multiple morbidities, such as heart disease and vulnerability to stress, are the main confounding factors that may impact to immune functions of elderly. Aging affects both cellular and humoral responses of the innate and adaptive immune systems and causes decreasing the number of immune cells, their viability, functional capacity and their responses against pathogens that entering the body. Strategies for preventing these diseases would have a clear impact on improving healthy aging. Thus, vaccination strategies for elderly population are needed. Vaccines should be developed to take into consideration the peculiar age-induced variations of immune responsiveness.
\end{abstract}

Keyword : aging, immune systems, vaccination

\section{Pendahuluan}

Populasi penduduk lanjut usia (lansia) di dunia terus meningkat. Penduduk diatas usia 60 tahun meningkat dari $8 \%$ pada tahun 1950 menjadi $10 \%$ pada tahun 2000, dan diperkirakan akan mencapai $21 \%$ pada tahun 2050 (Compte and Goriely, 2012). Dalam dua dekade terakhir, di Indonesia terdapat peningkatan populasi penduduk di atas 65 tahun dari $1,1 \%$ menjadi $6,3 \%$ dari total populasi. Pada tahun 1997, terdapat peningkatan 5,2\% penduduk usia lanjut di Indonesia. Diperkirakan proporsinya akan meningkat dua kali pada tahun 2020 menjadi 28,8 juta atau $11,34 \%$ dari seluruh populasi (Depkes RI, 2003).

$\mathrm{Di}$ sisi lain muncul fenomena peningkatan usia harapan hidup. Di negara maju, peningkatan usia harapan hidup mencapai hampir dua kali lipat dari 45 tahun pada tahun 1900 menjadi 80 tahun di tahun 2000 (Compte and Goriely, 2012). Fenomena ini disebabkan oleh adanya perbaikan status kesehatan, kemajuan teknologi dan penelitian di bidang kedokteran, transisi epidemiologi dari penyakit infeksi menuju penyakit degeneratif, perbaikan status gizi, pergeseran gaya hidup, dan peningkatan pendapatan per kapita (Fatmah, 2006).
Usia lanjut dihubungkan dengan tingginya angka mortalitas dan morbiditas. Usia lanjut dapat mempengaruhi beberapa aspek kehidupan, diantaranya terjadi perubahan fisik, biologis, psikologis, dan sosial sebagai akibat proses penuaan atau munculnya penyakit degeneratif (Fatmah, 2006). Kerentanan individu lanjut usia terhadap beberapa penyakit disebabkan oleh karena menurunnya imunitas. Proses penuaan meningkatkan kecenderungan untuk menderita infeksi parah yang merupakan penyebab utama tingginya mortalitas dan morbiditas pada usia lanjut (Boraschi et al., 2013). Oleh karena itu, pencegahan penyakit infeksi merupakan langkah yang penting untuk dilakukan. Artikel ini membahas perubahan respon imun akibat proses penuaan dan langkah preventif untuk meningkatkan status kesehatan individu lanjut usia dengan vaksinasi.

\section{Sistem Imun pada Usia Lanjut}

Penuaan diartikan sebagai penurunan kemampuan jaringan untuk memperbaiki diri serta mempertahankan struktur dan fungsi normal secara perlahan, sehingga tidak dapat bertahan terhadap jejas dan tidak dapat memperbaiki kerusakan yang diderita. Proses penuaan menyebabkan gangguan di tingkat selular seiring dengan bertambahnya usia 
sehingga menyebabkan penurunan viabilitas sel dan dapat berakhir dengan kematian (Darmojo dan Boedhi, 2006).

Sistem imun berperan dalam mencegah infeksi dan memerangi serangan mikroorganisme yang masuk ke dalam tubuh. Sistem imun mencakup dua bagian besar yaitu sistem imun bawaan (innate atau non spesifik) dan sistem imun didapat (acquired atau spesifik). Sistem imun bawaan merupakan mekanisme pertahanan melawan organisme yang menginvasi, sedangkan sistem imun didapat bekerja sebagai pertahanan tahap kedua (Dey et al., 2012). Fungsi sistem imun menurun dengan bertambahnya usia, sehingga meningkatkan resiko beberapa penyakit diantaranya penyakit infeksi, kanker, autoimun, penyakit kronis maupun penyakit degeneratif. Hal ini disebabkan oleh perjalanan alamiah penyakit yang berkembang secara lambat dan gejalanya tidak terlihat hingga beberapa tahun kemudian (Aspinall, 2005).

Faktor perancu utama yang berpengaruh pada fungsi imun individu usia lanjut adalah adanya beragam morbiditas dan kerentanan mereka terhadap stress. Patologi penyakit seperti kardiovaskuler, Diabetes mellitus, penyakit neurodegeneratif, dan osteoporosis dapat berefek langsung pada sistem imun (Compte and Goriely, 2012). Stres juga dapat melemahkan sistem imun dan mempengaruhi kesehatan sehingga memudahkan individu lanjut usia untuk terserang penyakit. Saat terjadi stress, hormon glukokortikoid dan kortisol yang dilepaskan akan memicu reaksi inflamasi (Fagundes et al., 2012).

\section{Efek Penuaan pada Sistem Imun Bawaan (Innate Immune System)}

Disfungsi aktivitas makrofag tidak semata-mata disebabkan oleh penurunan produksi sitokin, akan tetapi lebih dikarenakan faktor intrinsik yang dihubungkan dengan penuaan. Stimulasi makrofag pada tikus usia tua oleh lipopolisakarida (LPS) tidak mampu menghasilkan aktivitas untuk melisis tumor dan kadar Nitrite Oxyde Synthase (NOS) sebaik tikus muda. Makrofag tikus usia tua menghasilkan $\mathrm{H}_{2} \mathrm{O}_{2}$ dan NO kurang dari $50 \%$ dibandingkan tikus muda. Kondisi ini mempengaruhi kemampuan makrofag dalam membunuh mikroorganisme intrasel dan melisis sel tumor. Makrofag tikus usia tua juga mensekresi substansi yang bersifat supresif terhadap sistem imun seperti Prostaglandin E2 yang memiliki efek penghambatan terhadap sel dendritik dan sel T (Pawelec et al., 1998). Makrofag tikus usia tua mengekspresikan lebih sedikit reseptor Toll-like dan terdapat gangguan pada sekresi sitokin seperti IL-6 dan TNF- $\square$. Monosit dan makrofag dari tikus usia tua tampak menghambat respon proliferasi sel $\mathrm{T}$ (Linton dan Doorshkind, 2004).

Pada usia lanjut, dijumpai penurunan fungsi netrofil yang dihubungkan dengan penurunan kemampuan dan reaktivitas terhadap granulocyte colony-stimulating factor (G-CSF), IFN- $\square$ dan faktor pertumbuhan. Kerusakan fungsi sel PMN menyebabkan penurunan efisiensi sinyal transmembran dalam PMN seperti gangguan metabolisme kalsium. Di sirkulasi, dijumpai adanya peningkatan jumlah sel Natural Killer (NK) akibat perpindahan fenotif pada status maturitas. Akan tetapi berkebalikan dengan jumlahnya, sel NK menunjukkan aktivitas sitolitik yang menurun sesuai usia. Hal ini dibuktikan pada penelitian dimana sel CD16+ dari donor tua mengikat target menggunakan hanya setengah aktivitas lisis sel NK dibandingkan donor muda. Pada usia lanjut juga terdapat penurunan kemampuan sel dendritik dalam mempresentasikan antigen ke sel T. Kondisi ini memicu terjadinya toleransi imunologi dan meningkatkan insiden penyakit autoimun (Boraschi et al., 2013).

\section{Efek Penuaan pada Sistem Imun Didapat (Adaptive Immune System)}

Proses penuaan mempengaruhi Hematopoietic stem cell (HSC). HSC didefinisikan dari kemampuannya untuk berproliferasi dan membentuk HSC baru. Kemampuan HSC untuk berproliferasi menurun dengan bertambahnya usia. Produksi sel darah menunjukkan keseimbangan antara pembentukan HSC baru dan produksi sel anak dari galur mieloid atau limfoid. Penelitian menunjukkan bahwa sumsum tulang dari tikus tua tidak efisien untuk membentuk keturunan limfoid. Selain itu keturunan limfoid yang dihasilkan mengalami defek pada kemampuan hidup dan proliferasinya (Linton dan Doorshkind, 2004).

Involusi timus dan penurunan limfosit $\mathrm{T}$ merupakan gambaran yang umum dari perubahan sistem imun akibat penuaan (Fatmah, 2006). Timus merupakan organ tempat diferensiasi dan maturasi sel limfosit $\mathrm{T}$. Fungsi timus mulai menurun pada usia 1 (satu) 
tahun dan penurunannya signifikan setelah usia 40 (empat puluh) tahun. Perluasan ruang perivaskuler yang berisi jaringan adiposa, limfosit perifer dan stroma menyebabkan ruang epitel timus yang tersisa kurang dari 10\% dari total jaringan timus pada usia 70 tahun. Diramalkan timus berhenti memproduksi sel $\mathrm{T}$ baru pada usia 105 tahun (Ongradi \& Kovesdi, 2010). Atrofi timus dimediasi oleh peningkatan sitokin timosupresif seperti IL-6 dan penurunan sitokin timostimulator seperti IL-7. IL-7 berperan penting untuk mempertahankan fungsi timus dan memicu timopoiesis dengan mempertahankan protein antiapoptosis $\mathrm{Bcl}-2$ (Gruver et al., 2007).

Pada proses penuaan perubahan lambat dan masa hidup yang panjang dari sel $\mathrm{T}$ naive dapat dipertahankan, akan tetapi involusi timus yang terjadi secara bertahap menyebabkan ketidakmampuan untuk menggantikan sel $\mathrm{T}$ naive yang hilang dari sirkulasi. Selain itu, penuaan juga dihubungkan dengan penurunan fungsi sel $\mathrm{T}$ naïve. Dibandingkan dengan tikus muda, $40 \%$ sel $\mathrm{T}$ naive CD8+CD28+ tikus tua tidak mengekspresikan CD62L dan CCR7, reseptor yang berperan dalam migrasi ke jaringan limfe perifer. Sel T naive CD8 tampak lebih rentan terhadap apoptosis yang diperantarai reseptor kematian dari pada sel $\mathrm{T}$ CD4. Pada stimulasi poliklonal, sel $\mathrm{T}$ CD45RA+CD28+CD8+ dari individu usia lanjut menghasilkan lebih banyak IFN- $\square$ dari pada usia muda (Compte and Goriely, 2012).

Paparan kronis terhadap patogen dan antigen dari lingkungan sebaliknya dapat memicu peningkatan sel memori dan akan jatuh pada kondisi kepayahan. Infeksi kronis Cytomegalovirus (CMV) diduga merupakan stimulus utama pada proses replicative senescence. CMV dihubungkan dengan ekspansi klonal sel $\mathrm{T}$ CD8, meningkatkan jumlah sel T CD8+CD28-, efektor sel T memori yang mengekspresikan CD45RA CCR7- dan membalik rasio CD4:CD8 (Aspinall, 2005). Sel $\mathrm{T}$ yang mengalami ekspansi klonal ( $T$ Cell Expansion /TCE) kurang efektif dalam melawan penyakit. TCE mampu berakumulasi secara cepat karena memiliki rentang hidup yang panjang. Perbanyakan populasi sel TCE dihubungkan dengan penurunan efektifitas sistem imun dalam memerangi beberapa patogen. Hal ini telah dibuktikan pada studi yang dilakukan terhadap tikus dimana ditemukan bahwa tikus berusia lanjut mempunyai jumlah TCE lebih besar dibandingkan tikus normal, populasi sel T CD8 yang kurang beragam, dan penurunan kemampuan melawan penyakit (Bell, 1997).

Sel B progenitor mengalami diferensiasi dan maturasi di jaringan limfe sekunder seperti limpa dan nodus limfe. Usia lanjut dihubungkan dengan perubahan dalam limpa mencakup penurunan arteri, peningkatan sel stroma dan infiltrasi fibroblast (Gruver et $a l .$, 2007). Kondisi ini menyebabkan gangguan dalam jumlah dan fungsi sel B yang dihasilkan. Penurunan produksi IL-7 memicu penurunan kemampuan untuk mendukung ekspansi sel B oleh sel stroma sumsum tulang. Jumlah sel B (CD19+) juga menurun pada usia lanjut. Proporsi $\operatorname{IgG}-\operatorname{Ig} \mathrm{A}-\operatorname{IgD}+\mathrm{CD} 27-m e n u r u n$ sesuai usia dan menunjukkan penurunan kerentanan terhadap apoptosis. IgM memori diketahui juga menurun dengan bertambahnya usia (Ongradi \& Kovesdi, 2010).

Kualitas respon humoral juga menurun akibat usia lanjut, ditandai oleh penurunan kemampuan tubuh untuk memproduksi antibodi. Antibodi yang dihasilkan juga memiliki durasi respons yang lebih singkat. Sehingga pada usia lanjut cenderung terjadi autoantibodi dan mengarah pada penyakit autoimun seperti Rheumatoid arthritis dan atherosclerosis. Penurunan fungsi sel $\mathrm{T}$ pada usia lanjut juga mempengaruhi fungsi sel $\mathrm{B}$ karena sel $\mathrm{T}$ dan sel B bekerjasama untuk mengatur produksi antibodi. Sel T menginduksi sel B untuk melakukan hipermutasi gen-gen immunoglobulin, menghasilkan perbedaan antibodi untuk mengenali jenis-jenis antigen (Ongradi \& Kovesdi, 2010).

\section{Mekanisme Penurunan Respon Imun Akibat Proses Penuaan}

Penurunan respon imun pada usia lanjut diduga didasari oleh beberapa penyebab diantaranya pemendekan telomere, faktor genetik dan perubahan hormonal. Telomer berfungsi menutup ujung kromosom sehingga dapat membedakan ujung kromosom dari DNA yang rusak dalam genom. Kerusakan DNA memicu gangguan dalam siklus sel dan perbaikan DNA atau memicu apoptosis jika kerusakannya parah. Sebaliknya, ujung kromosom tidak memicu respon kerusakan DNA (Ongradi \& Kovesdi, 2010). Pemendekan telomer dihubungkan dengan masalah replikasi DNA polymerase pada masing-masing siklus pembelahan sel dan untuk mengurangi aktivitas telomerase yang gagal untuk menambahkan 
sekuens ulang telomer ke ujung kromosom. Telomer memendek $50-100$ bp tiap siklus pembelahan. Jaringan manusia yang menunjukkan adanya pemendekan telomer selama proses penuaan diantaranya PBMC, limfosit, epitel ginjal, sel endotel vaskuler, hepatosit, sel epitel intestin dan paru, dan otot. Individu dengan telomere pendek memiliki 3,8 kali lebih tinggi angka mortalitas akibat penyakit jantung dan 8,54 kali lebih tinggi terhadap penyakit infeksi dibandingkan dengan individu yang memiliki telomer panjang. Pemendekan telomer akibat usia lanjut diobservasi dari PBMC terjadi pada berbagai penyakit seperti sindroma mielodisplasi, aterosklerosis, hipertensi, coronary artery disease, HIV, Rheumatoid arthritis, SLE dan penurunan kognitif seperti pada penyakit Alzheimer (Jiang et al., 2007).

Stres oksidatif diduga merupakan faktor utama yang mempercepat proses penuaan, kemungkinan dihubungkan dengan peningkatan aktivitas pemendekan telomer sebagai hasil kerusakan DNA akibat merokok, obesitas ataupun penyakit kardiovaskuler (Andrews et al., 2010). Insiden kanker meningkat sesuai usia. Pemendekan telomer tampak memiliki dua peran pada kanker, membatasi masa hidup sel normal dan berperan sebagai tumor supresor. Mayoritas sel kanker menunjukkan telomer yang sangat pendek. Telomerase mampu memperpanjang telomer oleh karena adanya peningkatan regulasi bersamaan dengan aktivasi sel T, akan tetapi aktivitas enzim ini mati pada sel T CD8+ yang distimulasi secara kronis pada kultur sel. Ini menunjukkan bahwa salah satu cara untuk meningkatkan respon imun pada usia lanjut adalah dengan meningkatkan aktivitas telomerase (Compte and Goriely, 2012).

Faktor genetik juga berperan dalam proses immunosenescence. Sebagai contoh, gen IL-6 terlibat dalam regulasi genetik dari usia. Genotif IL-6 VNTR D/D dihubungkan dengan peningkatan kadar dalam darah dan otak dari pasien Alzheimer dan IL-6 VNTR alel B dapat rusak pada usia lanjut yang ekstrim. Dilaporkan juga bahwa polimorfisme promoter IL-10 -1082 meningkat pada orang berumur diatas 100 tahun dibandingkan dengan usia muda dan dihubungkan dengan peningkatan produksi IL10 (Krabbe et al., 2004).

Usia juga dihubungkan dengan perubahan hormonal. Penelitian menunjukkan bahwa defisiensi estrogen memicu penurunan ekspresi IL-2. Estrogen tampak berperan penting pada sel $\mathrm{B}$, dibuktikan dengan penelitian dimana jumlah sel B menurun secara signifikan pada menopause (Ku et al., 2009). Hormon DHEA (Dehydroepiandrosterone) erat hubungannya dengan penurunan fungsi kekebalan tubuh. Kadarnya dalam serum menurun dramatis dengan pertambahan usia baik pada laki-laki maupun wanita. Meskipun sel $\mathrm{T}$ tidak memiliki reseptor spesifik untuk DHEA, diduga mekanisme kerjanya melalui konversi menjadi steroid lain terutama hormon steroid seks (Compte and Goriely, 2012).

\section{Vaksinasi pada Lanjut Usia, Peluang dan Tantangannya}

Vaksinasi bertujuan untuk memelihara sistem imun dalam melawan agen infeksi. Vaksin mengandung substansi antigen yang sama dengan patogen asing agar sistem imun dapat mengenal patogen asing dan menghasilkan sel $\mathrm{T}$ dan sel $\mathrm{B}$. Vaksinasi merupakan strategi untuk meningkatkan sistem imun idividu lanjut usia dalam rangka menurunkan morbiditas dan mortalitas yang dihubungkan dengan infeksi (Dey et al., 2012). Kampanye vaksinasi pada lanjut usia telah menurunkan $25 \%$ morbiditas, $50 \%$ pneumopati, $20 \%$ perawatan di rumah sakit, dan $70 \%$ mortalitas (Ongradi \& Kovesdi, 2010).

Influenza dan pneumonia merupakan penyebab kematian keempat pada individu usia 65 tahun atau lebih. Center for Disease Control (CDC) merekomendasikan individu berusia diatas 50 tahun untuk melakukan vaksinasi pneumonia pneumokokus dan influenza. Vaksin influenza sebaiknya diberikan pada orang lanjut usia setiap tahun sebelum musim flu tiba. Vaksin ini menurunkan kurang lebih 30\% kemungkinan perawatan rumah sakit akibat penyakit vaskuler (infark miokard atau strok) dan pneumonia yang dihubungkan dengan influenza. Vaksin pneumokokus memiliki efektivitas proteksi mencapai $60-70 \%$ dalam melawan infeksi pneumokokus yang invasif. Injeksi dosis tunggal polivalen harus diberikan pada individu berusia 65 tahun yang belum pernah menerima imunisasi sebelumnya. Dosis kedua direkomendasikan diberikan 5 tahun setelah dosis pertama pada usia 19-64 tahun dengan asplenia dan penurunan imunitas akibat penyakit keganasan hematologi, gagal ginjal, atau terapi kortikosteroid jangka panjang. Vaksin Herpes Zooster juga direkomendasikan diberikan pada lanjut usia untuk menurunkan kejadian infeksi herpes dan komplikasi 
khususnya neuralgia paska infeksi herpes. Food Drug Association (FDA) merekomendasikan Zostavax dosis tunggal digunakan pada usia 60 tahun atau lebih untuk mencegah radang saraf tanpa melihat apakah mereka telah terinfeksi chickenpox atau tidak. Vaksin ini menurunkan insiden peradangan saraf mencapai $51,3 \%$ dan neuralgia paska infeksi herpes sebanyak $66,5 \%$ (Dey et al., 2012).

Tantangan pemberian vaksin pada lanjut usia diakibatkan oleh pengaruh proses penuaan dalam memfasilitasi respon antibodi setelah vaksinasi (Fagundes et al., 2012). Individu lanjut usia menunjukkan respon yang lebih rendah terhadap vaksin influenza, dibuktikan pada penelitian yang menunjukkan bahwa individu lanjut usia memiliki titer antibodi yang lebih rendah dibanding kontrol (Kiecolt-Glaser et al., 2003). Penurunan TNF- $\square$ dan peningkatan produksi IL-10 dihubungkan dengan respon antibodi yang rendah terhadap vaksinasi influenza. IL-10 bekerja dengan menghambat maturasi antigen presenting cell (APC) dan menginduksi anergi sel T CD4. Genotif sistem imun tampak demikian meningkat pada individu lanjut usia dihubungkan dengan efek protektif terhadap penyakit neurodegeneratif (Corsini et al., 2006)

Penelitian lain yang menguji respon vaksin pneumonia peumokokus pada individu lanjut usia menunjukkan bahwa meskipun 2-4 minggu setelah vaksinasi, titer antibodi sama dengan kontrol, akan tetapi setelah 3-6 bulan kemudian titer antibodi individu lanjut usia sangat menurun jika dibandingkan dengan kotrol (Glaser et al., 2000). Sedangkan vaksin tetanus, difteri, pertusis dan hepatitis B tidak mampu menghasilkan antibodi protektif pada individu diatas usia 60 tahun (Chen et al., 2009).

Desain pemberian vaksinasi pada lanjut usia penting dilakukan untuk meningkatkan efektivitas vaksin. Desain ini meliputi jadwal vaksinasi, dosis vaksin, rute pemberian vaksin dan kombinasi dengan adjuvan. Formulasi adjuvan merupakan salah satu cara untuk meningkatkan efektivitas vaksin. Penggunaan adjuvan minyak dalam air, seperti MF59 dan AS03, menghasilkan respon yang sangat bagus dalam meningkatkan respon imun usia lanjut terhadap vaksinasi influenza. Vaksinasi flu musiman dengan adjuvant MF59 pada individu usia tua diketahui bekerja sebagai boster imun, menginduksi titer antibodi spesifik dan meningkatkan jumlah epitop yang dikenali sel
B (Boraschi et al., 2012). Kerusakan fungsi TLR pada individu usia lanjut memungkinkan penggunaan agonis TLR dalam vaksin. Oligonukleotida yang menggandung $\mathrm{CpG}$ digunakan sebagai adjuvant vaksin konjugat pneumokokus dan diketahui secara signifikan dapat meningkatkan respon vaksin pada penderita HIV. MPL yang merupakan derivat lipid A dari lipopolisakarida juga digunakan sebagai adjuvan dalam vaksin Human Papilloma Virus (Cervarix) (Shaw et al., 2011).

\section{Penutup}

Penuaan berpengaruh baik terhadap sistem imun bawaan maupun sistem imun didapat melalui beberapa mekanisme diantaranya pemendekan telomer, faktor genetik dan perubahan hormonal. Vaksinasi merupakan strategi preventif untuk meningkatkan imunitas lanjut usia. Meskipun respon imun sangat menurun akibat proses penuaan, akan tetapi formulasi adjuvan yang tepat dapat meningkatkan efektivitas vaksin. Pemahaman mengenai mekanisme adjuvan dalam meningkatkan efektivitas vaksin dibutuhkan untuk mengembangkan respon vaksin yang lebih kuat pada individu usia lanjut.

\section{Daftar Pustaka}

Aspinall R. 2005. Ageing and the Immune System in vivo: Commentary on the 16th session of British Society for Immunology Annual Congress. Biomed Central. Vol. 2 No. 5.

Bell R, High K. 1997. Alterations of Immune Defense Mechanisms in The Elderly: the Role of Nutrition. Infect Med. Vol 14.

Boraschi D. 2013. The Gracefully Aging Immune System. Science Translational Medicine. Vol 5.

Chen,W.H. 2009. Vaccination in the elderly: an immunological perspective. Trends Immunol. Vol. 30 No. 7.

Compte, Nathalie dan Goriely, Stanislas. 2012. Innate Immune Responses in the Geriatric Population, Recent Advances in Immunology to Target Cancer, Inflammation and Infections. Online. http://www.intechopen.com/books/rece nt-advances-immunology- totargetcancer-inflammation-andinfections/Innate-immune-responses-in- 
the-elderly. diakses tanggal 20 Mei 2014.

Corsini, E. 2006. High interleukin-10 production is associated with low antibody response to influenza vaccination in the elderly. J.Leukoc.Biol. Vol. 80 No.2.

Darmojo dan Boedhi, R. 2006. Buku ajar Geriatri Ilmu Kesehatan Lanjut Usia. Jakarta: FK-UI.

Departemen Kesehatan RI. 2003. Pedoman Tatalaksana Gizi Usia Lanjut untuk Tenaga Kesehatan. Jakarta : Direktorat Bina Gizi Masyarakat Ditjen Binkesmas Depkes RI,

Dey, AB. Chatterjee, Prasun. Das, PC. 2012. Immune Status in the Elderly. Medicine update. Vol 22.

Fagundes, CP. 2012. Resilience and Immune Function in Older Adults. Springer Publishing Company. Online. http://dx.doi.org/10.1891/01988794.32.29. diakses tanggal 20 Mei 2014.

Fatmah, 2006. Respon Imunitas yang Rendah pada Tubuh Manusia Usia Lanjut. Makara Kesehatan. Vol 10 No 1.

Glaser, R., Sheridan, J., Malarkey, W. B., MacCallum, R. C., dan Kiecolt-Glaser, J. K. 2000. Chronic stress modulates the immune response to a pneumococcal pneumonia vaccine. Psychosomatic Medicine. Vol. 62 No. 6.

Gruver,A.L., Hudson, L. L., \& Sempowski, G. D. 2007. Immunosenescence of ageing. J.Pathol. Vol. 211 No.2.

Jiang, H. Ju, Z. Rudolph, K. 2007. Telomere shortening and ageing. Gerontol.Geriatr. Vol. 40 No.5.

Kiecolt-Glaser, J. K. 2003. Chronic stress and age-related increases in the proinflamatory cytokine IL-6. Proceedings of the National Academy of Sciences of the United States of America, 100 (15).

Krabbe, K.S., Pedersen, M., dan Bruunsgaard, H. 2004. Inflammatory mediators in the elderly. Exp.Gerontol. Vol.39, No.5.

Linton, Phyllis Jean dan Doorshkind, Kenneth. 2004. Age-related changes in lymphocyte development and function. Nature Immunology. Vol 5 No 2.
Ongradi, J. dan Kovesdi, V. 2010. Factors that may impact on immunosenescence: anappraisal. Immun.Ageing. Vol.7.

Pawelec, Graham. Solana, Rafael. Remarque, Ed. Mariani, Erminia. 1998. Impact of Aging on innate immunity. Journal of Leukocyte Biology. Vol. 64.

Vasto, Sonya. Malavolta, Marco. Pawelec, Graham. 2006. Short report : Age and immunity. Immunity and Ageing. Vol 3 No 2. 